\title{
Antagonistic Effect of Rhizobium, Bacillus, Pseudomonas, Trichoderma on Fusarium and Rhizocotonia Compared with Moncut In Vitro. El-Sebaay, H. H. ${ }^{1}$ and A. B. El-Sayed ${ }^{2}$ \\ ${ }^{1}$ Botany Department (Microbiology) Faculty of Agriculture Al-Azhar University Cairo. ${ }^{2}$ Plant Pathology Research Institute, Agricultural Research Center (ARC), Giza, Egypt.
}

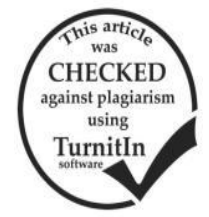

ABSTRACT

This investigation was carried out in 2018 to study activity Rhizobium leguminosarum biovarphaseoli, Bacillus subtilis, Pseudomonas fluorescens,Trichoderma album and T. hamatum against of some soil pathogenic plant fungi; Fusarium oxysporum and Rhizoctonia solani causative agents root rot disease of common bean was evaluated on culture medium. The bio-agent Rhizobium was checked as culture filtrate, different concentrations; $25,50,100,150,200$ and $250 \%$, also by their cells as opposite to test fungi to observe effect on radial growth and inhibition zone percent by dual method compared with control. In addition bio agent effect was compared with effect of Moncut fungicide; different concentrations; 1, 10, 25, 50 and $100 \mathrm{ppm}$ by agar well diffusion method.The obtained results revealed that bio - agents gave significance effect and maximum inhibition growth of Fusarium oxysporium and Rhizoctonia solani compared with control as well as Moncut fungicide. Overall rhizobia nitrogen fixing, growth regulators production, also gave inhibition growth of test fungi reached $89.50,90.29 \%$ and in cultural filtrate conc.100\% manner, but cells treatment were, $59.96 \%$ and $38.86 \%$ in the previous order.

Keywords: Antagonism, Rhizobia, Bacillus, Pseudomonas,Trichoderma on Fusarium, Rhizoctonia , radial growth , inhibition percent, Moncut fungicide.

\section{INTRODUCTION}

Due to great harms caused by chemiecal pesticied control of some soil pathogenic plant, there is effect on enviorenment and public health. The researches towerds to bio-agent control by non-pathogenic and save microorganisms, adabted and alternative of chemical pesticide. Elbatanony et al. 2007; Mazen et al. 2008 ,Shanker and Shyam 2014).

A number of fungi and bacteria are known to be very effective to bio-agent against soil-borne plant pathogenic fungi ( Shoda 2000).Bacillus-based biological control agents have great potential in integrated disease management (IDM) options,together with cultural control, resistant cultivars, fungicides or others biological control agents (Jacobsen et al., 2004). Genus Bacillus comprises a heterogeneous groups can be survive in many diverse environments, often with extreme variations in temperature, nutrient, and other stresses (Driks, 2004). These properties are associated with the ability to produce peptide antibiotics and contribute to the utilization of Bacillus spp. to manage several root and foliar diseases (Kloepper et al., 1999; Driks, 2004). In addition found that Actinomycetes, Bacillus licheneforms and fungi their effect by antimicrobial production (Abd-Elkhaleik et al., 2018 ). Enzymes, for example, chitinase that can lyses cell walls plant pathogenic fungi.(El-Mehalawy 2004), or plant growth enhancement through IAA production (Deshwal, et al., 2003; Shoukry et al.,2018).

The inhibitory effect of cultural filtrate of some wild rhizobial isolates (M.L, L.C , 4 T.S and $R$. leguminosarum ICARDA 441 strain) against some fungi causing root rot disease of faba bean ( $R$. solani, Fusarium spp. and $F$. solani) in vitro and their antimicrobial synergetic effect when combined with Arbuscular mycorrhiza (AM) fungi, were investigated.(El-Batanony et al. 2007). The bio-control agents have different mechanisms or combinations of mechanisms which may be involved in the suppression of different plant disease; for example, inhibition of pathogen by antimicrobial substances (antibiosis) (El-Mehalawy 2004); or production of diverse microbial metabolites like siderophore, rhizobiotoxin (Deshwal, et al. 2003); competition for nutrients supplied by seeds and roots and colonization sites; induction of plant resistant mechanisms; inactivation of pathogen germination factors present in seed and root exudates and degradation of pathogenicity factors of the pathogen such as toxins;parasitism that may involve production of extracellular cell wall-degrading.

The present study was evaluated the effect of Rhizobium leguminsarum bv. phaseoli ; Bacillus subtilius; Pseudomonas fluorescens; T. album; T. hamatum against Rhizoctonia solani and Fusarium oxysporium. In vitro the bioagent was checked as clture filtrate and measure. Agrowth and inhibition percent of Fusarium oxysporium and Rhizoctonia solani. In addition bio- effect of Bacillus subtillus, Pseudomonas fluoresence, T. hamatum and $T$. album on some soil fungi compared with moncut fungicide on medium.

\section{MATERIALS AND METHODS}

Materials: Antagonistic bio-agents bacteria Rhizobium leguminsarum bv. phaseoli (pea group) and Bacillus subtilis were taken from performer work and reconfermed to purified and identified characteristics. But Pseudomonas flurescnce, Trichoderma album and T. hamatum as well as test fungi (Fusarium oxysporium ,Rhizoctonia solani) as casative root rot plant pathogenic ; also fungicide moncot as. Each were carried out by plant pathology Institute, Agric. Res. Center. Minstry of Agiculture.

Methods: Antgonistic action was applied by agar well diffusion method on the solid medium as follow: Preparation of tested fungi casative root rot plant pathogenic fungi; Fusarium oxysporium and Rhizoctonia solani was prepared separately by inoculation on petri dishs of potato dixtrose agar (PDA) medium under asceptic condition and inocubation at $30 C^{0}$ for 7 days.

Preparation of antagonistic microoganims: The antagonistic bacteria of Rhizobium leguminsarum $b v$. phaseoli inoculum produced by growing in (YEM) broth medium containing; Manitol $10 \mathrm{~g} / \mathrm{l}$, Yeast extract $1 \mathrm{~g} / \mathrm{l}, \mathrm{K} 2 \mathrm{HPO} 4 \quad 0.5 \mathrm{~g} / \mathrm{l}, \mathrm{MgSO} 4 \quad 0.2 \mathrm{~g} / \mathrm{l}, \mathrm{NaCl} \quad 0.1 \mathrm{~g} / \mathrm{l}$, agar $20 \mathrm{~g} / \mathrm{l}$,Distilled water $1000 \mathrm{ml}$, Congored $10 \mathrm{ml}, \mathrm{pH} 7.2$. After sterilization, medium inoculated and inocubated at $30 \mathrm{C}^{0}$ for $48 \mathrm{~h}$. To Bacillus subtilis and Pseudomonas flurscncnce inoculum production by growing separatly on nutreint broth medium and inocubation at $30 \mathrm{C}^{0}$ for $48 \mathrm{~h}$. 
The inoculum of antagonistic fungi; Trhicoderma album and T. hamatum production separatly by inoculation on (PDA) petri dishes medium and inocubation at $30 \mathrm{C}^{0}$ for 7 days.

Antagonistic application: All antagonistic tests were done on $9 \mathrm{~cm}$ petri dishes three replicates to calculate the clear zones have been seen at 7days of incubation compared with control.

Antagonistic action between Rhizobium theirfore bring organism or their culture filtrate with test fungi; Fusarium oxysporium and Rhizoctonia solani was checked invidiualy. Rhizobial cells was streaked on oppsite side equal distance $5 \mathrm{~cm}$ from test fungi, but rhizobial culture filtrate was experminted by filtration $5 \mathrm{ml}$ of broth rhizobial growing medium by using millibor filter syring $(045 \mu \mathrm{m})$ under aceptic condition. The cluture filtrat was injected as $1 \mathrm{ml}$ in agar well oppsite $5 \mathrm{~cm}$ side distance from dsic test fungi. After inocubation resultes were observed and recorded of radial growth and inhibition zone compared with control test fungi alone,both experimental and control Petri plates were arranged in a completely randomized design with three replicates per treatment. Petri plates were incubated at $28 \pm 2{ }^{\circ} \mathrm{C}$ for 7 days. The percentage fungal radial growth inhibition was calculated by following formula:

For antagonistic by Bacillus subtilus and Pseudomonas flourescence were examined Fusarium oxysporum and Rhizoctonia solani by growing in nurient broth medium and inocubation at $30^{\circ} \mathrm{C}$ for $48 \mathrm{~h}$. The test organism fungi was inoculated as disc on PDA medium and antagonistic organism was straked on opsite side of petri dish as three plats replicates of each fungi indvidiually treatment. After inocubation period for 4days the radial growth of fungi and inhibition zone percent were observed, measured and recorded compared with pathogenic fungi alone as control.

For antagonistic root rot fungi by Trichoderma album and T.hamatum as bio-agent was carried by inoculation of test and antagonistic fungi as a disc separeatly each on one plate by use PDA medium. After that incubation at $30{ }^{0} \mathrm{C}$ for7 days, then under aceptic condition by cork porer get one disc of each put on one side opsite at equal distance $5 \mathrm{~cm}$ between two fungi. Inoculated plates were inocubated at $30^{\circ} \mathrm{C}$ for 4-6 days the results were observed, recorded and culculated compared with control (Titiya et al., 2007).

All bio-agent antagonistic treatment was compared with Moncut fungicide by different concentrations ; 1 ,10, 25, 50 and $100 \mathrm{ppm} / \mathrm{l}$. After inoculation pathogenic fungi as disc in PDA medium petri dish, agar well was done by cork porer, one $\mathrm{ml}$ of each concenration put in well of each test fungi.

Data analysis: The means were compared using the least significant difference test (LSD) between the antagonistic treatments at 0.05 and 0.01 significances (Steel et al., 1997).

\section{RESULTS AND DISCUSSION}

Antagonistic of bio-agents on Fusarium oxysporium : The results in Table (1) revealed that effect of bio-agents on mycelial expansion( linear growth $(\mathrm{cm})$, efficacy $(\%)$ and inhibition growth $(\mathrm{cm})$ by dual medium method as inoculum or disc opposite disc of test fungi. Antagonistic bacteria of $R$. leguminsarum biovar. Phaseoli was; $3.7 \mathrm{~cm}$, $59.96 \%$ and $1.86 \mathrm{~cm}$. It was pointed out by Chao that the Rhizobium leguminosarum biovar phaseoli had an effect on the inhibition of the Fusarium and Rhizoctonia species.Also Bacillus subtilis found to be $4.10 \mathrm{~cm}, 53.01 \%$ and $2.00 \mathrm{~cm}$. While the effect of $P$. fluorescence was; $4.16 \mathrm{~cm}, 53.01 . \%$ In addition the effect of $T$. album and $T$. hamatum were; $2.33 \mathrm{~cm}, 2.30 \mathrm{~cm}, 72.97 \%$ and $72.93 \%$ compared with control respectively.The researches towerds bio-agent control by non-pathogenic and save microorganisms, also adabted and alternative of chemical pesticide.Etheshaul- Haque \& Ghaffar 1993; Deshwal et al. 2003; Sharif et al.2003; Elbatanony et al. 2007; Mazen et al. 2008 , Shanker and Shyam 2014.

Table 1. Antagonistic effect of bio-agents on Fusarium oxysporium.

\begin{tabular}{|c|c|c|c|c|c|c|c|c|c|c|c|c|}
\hline \multirow{2}{*}{$\begin{array}{l}\text { Bio- agents } \\
\text { Isolates }\end{array}$} & \multicolumn{4}{|c|}{ Liner growth (cm). } & \multicolumn{4}{|c|}{ Efficacy \%. } & \multicolumn{4}{|c|}{ Inhibition zone (cm). } \\
\hline & R1 & $\mathbf{R 2}$ & R3 & M. & R1 & R2 & R3 & M. & R1 & $\mathbf{R 2}$ & R3 & M. \\
\hline R.leguminsarum bv.phaseoli & 3.50 & 3.60 & 4.00 & 3.7 & 66.25 & 59.09 & 54.55 & 59.96 & 1.90 & 2.00 & 1.70 & 1.86 \\
\hline B. subtilus & 4.00 & 4.00 & 4.30 & 4.10 & 54.55 & 55.05 & 51.64 & 53.01 & 2.00 & 2.00 & 2.00 & 2.00 \\
\hline P. florescence & 4.00 & 4.00 & 4.50 & 4.16 & 54.55 & 55.05 & 49.43 & 53.01 & 2.40 & 2.20 & 2.00 & 2.20 \\
\hline T. album & 2.30 & 2.20 & 2.00 & 2.33 & 73.86 & 73.16 & 71.91 & 72.97 & - & - & - & - \\
\hline T. hamatum & 2.0 & 2.40 & 2.50 & 2.30 & 73.86 & 73.03 & 71.91 & 72.93 & - & - & - & - \\
\hline Control & 8.80 & 6.80 & 8.90 & 8.16 & 00.00 & 00.00 & 00.00 & 00.00 & - & - & - & - \\
\hline L.S.D. & & 0 . & & & & 5.1 & & & & & & \\
\hline 0.01 & & 1. & & & & 7.1 & & & & 0 . & & \\
\hline
\end{tabular}

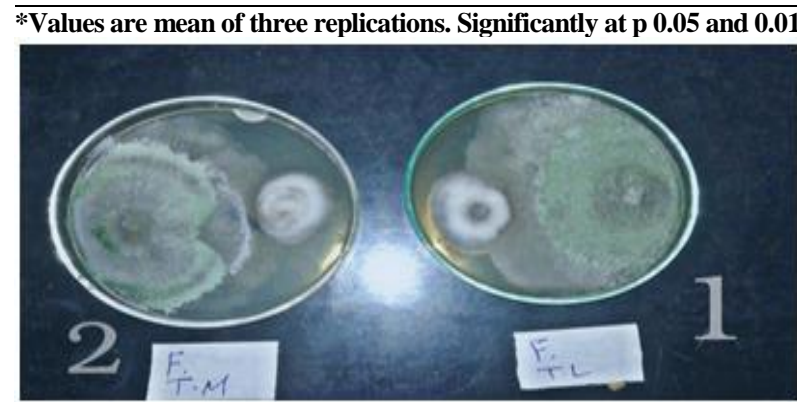

Photo 1. Antagonistic interaction between $F$. oxysporium $+1(T$. album $), 2(T$. hamatum). on dual media.

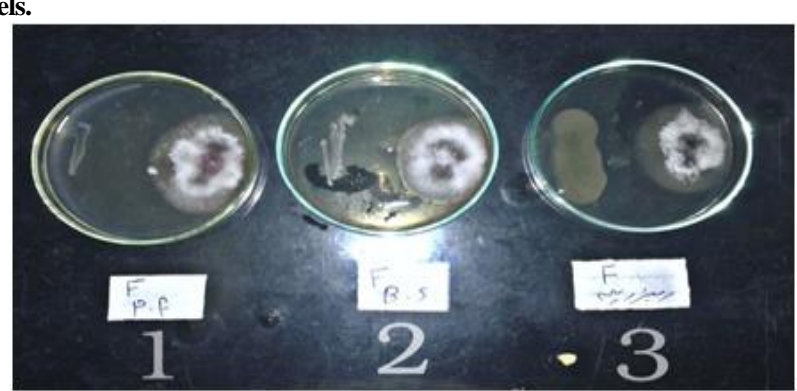

Photo 2. Antagonistic interaction between $F$. oxysporium with (1) P. flourescnce, (2) B. subtilius and (3) R. leguminsarum. 
There were significance at 0.05 were; $0.94,5.12$ and 0.18 , but at 0.01 were; $1.32,7.18$ and 0.26 of liner growth, efficacy and inhibition zone respectively. The results were agreement with investigators as;

Antagonistic of bio-agents microbes on Rhizoctonia solani: Data in Table(2) Improved that posative effect of bio-agents microorganisms on the radial growth $(\mathrm{cm})$ and reduction growth percent of Rhizoctonia solani by dual medium method.The mean results were; 4.93 and $38.86 \%$ against by R.leguminsarumbiovar.phaesoli, 5.53 and $29.91 \%$. Moreover, some works explained the antagonistic properties of Rhizobium leguminosarum against Fusarium oxysporum f.sp. lentis due to excretion of antibiotics that have fungicidal action on condia of $F$. oxysporum Essalmani and Lahlou (2002). Rhizobium was reported to produce toxic metabolites which have inhibitory effect against soil borne plant pathogens Estevez et al.(2002). Defago et al.(1990) have also demonstrated by mutational analysis and complementation that production of HCN by Pseudomonas fluorescens strain, CHAO accounted for about $60 \%$ of the biocontrol
activity.B. subtilus were;5.80 and $27.79 \%$, while $P$. florescence were 3.10 and $64.76 \%$ Kishore et al.(2005) demonstrated that Pseudomonas aeruginosa which produced protease had significant inhibition (> 32\%) against Sclerotium rolfsii. This is an indication that the enzyme protease has responsible effect on the phytophatogens. The T. album were , 3.43 and $61.12 \%$ in the other hand $T$. hamatum effect on the radial growth $(\mathrm{cm})$ and reduction growth \% compared with control respectively.Shoda, 2000 noteced that a number of fungi and bacteria are known to be very effective bio-agent against soil-borne plant pathogenic fungi.Jacobsen et al., 2004 showed that Bacillus-based biological control agents have great potential in integrated disease management (IDM) options, Together with cultural control, resistant cultivars, fngicides or others biological control agents.Driks, 2004 and Ahmed (2017) They found that Genus Bacillius comprises a heterogeneous groups can be survive in many diverse environments, often with extreme variations in temperature, nutrient, and other stresses.

Table 2. Antagonistic effect of bio-agents isolates on Rhizoctonia solani.

\begin{tabular}{|c|c|c|c|c|c|c|c|c|}
\hline \multirow{2}{*}{$\begin{array}{l}\text { Bio-agents } \\
\text { Isolates }\end{array}$} & \multicolumn{4}{|c|}{ Liner growth (cm) } & \multicolumn{4}{|c|}{ Reduction of radial growth \% } \\
\hline & R1 & R2 & $\mathbf{R 3}$ & M. & R1 & $\mathbf{R 2}$ & R3 & M. \\
\hline$\overline{\text { R.leuminsarum bv.phaesoli }}$ & 5.50 & 5.30 & 4.00 & 4.93 & 37.50 & 39.77 & 39.32 & 38.86 \\
\hline B. subtilis & 6.00 & 6.30 & 4.30 & 5.53 & 31.81 & 28.40 & 29.54 & 29.91 \\
\hline P. florescence & 6.50 & 6.40 & 4.50 & 5.80 & 26.13 & 27.72 & 29.54 & 27.79 \\
\hline T. album & 3.00 & 3.10 & 3.20 & 3.10 & 65.90 & 64.77 & 63.63 & 64.76 \\
\hline T. hamatum & 3.50 & 3.50 & 3.30 & 3.43 & 60.22 & 60.22 & 62.92 & 61.12 \\
\hline Control & 8.80 & 8.80 & 8.90 & 8.83 & 00.00 & 00.00 & 00.00 & 00.00 \\
\hline L.S.D. & \multicolumn{4}{|c|}{2.55} & \multicolumn{4}{|c|}{2.42} \\
\hline At & \multicolumn{4}{|c|}{3.57} & \multicolumn{4}{|c|}{3.39} \\
\hline
\end{tabular}

*Values are mean of three replications. Significantly at $\mathrm{p} 0.05$ and 0.01 levels.

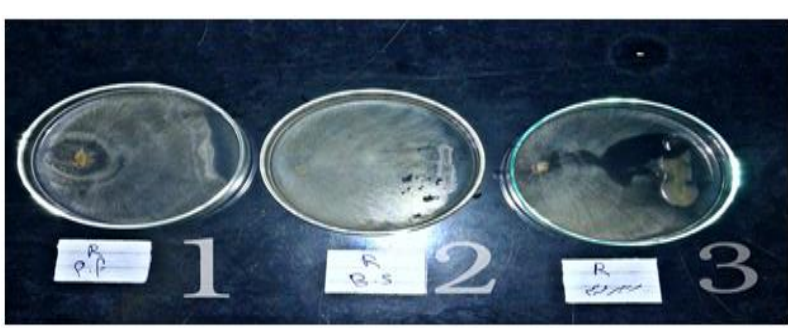

Photo 3. antagonistic interaction between $R$. solani $+(1)$ $P$. fluorescnce, (2) B. subtilius and (3) $R$. leguminsarum.

Effect of Moncut fungicide on Fusarium and Rhizoctonia growth on medium: The results in Table (3) showed that effect of moncut fungicide different concentrations on growth of Fusarium oxysporum and Rhizoctonia solani on medium. The concentrations $1,10,25,50$ and $100 \mathrm{ppm}$ from fungicide were checked on the inhibition growth $\%$ of tested

Fungi. The heist mean percent effect on $R$. solani was found that at $50 \mathrm{ppm} ; 86.06 \%$, also p. at 0.05 found 10.20 and 14.51 at 0.01 .

On the other hand effect on $F$. oxysporium was $86.03 \%$ at $50 \mathrm{ppm}$ and $\mathrm{P}$ at 0.05 was 6.64 and 9.45 at $\mathrm{P}$ 0.01 these results were the same trend by Ghada et al; (2013), Amany et al; (2016) Ibrahim et al (2016) and Karima et al, (2012).
Table 3. Effect of Moncut fungicide different concentrations on Fusarium oxysporum and Rhizoctonia solani growth.

\begin{tabular}{lcccccc}
\hline \multirow{2}{*}{$\begin{array}{l}\text { Test organism } \\
\text { Replicates }\end{array}$} & & \multicolumn{5}{c}{ Moncut concentrations (ppm) } \\
\cline { 2 - 7 } & & $\mathbf{1}$ & $\mathbf{1 0}$ & $\mathbf{2 5}$ & $\mathbf{5 0}$ & $\mathbf{1 0 0}$ \\
\cline { 2 - 7 } & $\mathrm{R} 1$ & 88.78 & 70.77 & 78.77 & 84.26 & 100 \\
R. & $\mathrm{R} 2$ & 88.88 & 80.88 & 82.02 & 88.39 & 100 \\
solani & $\mathrm{R} 3$ & 70.88 & 82.82 & 82.02 & 85.56 & 100 \\
& Mean & 82.84 & 78.15 & 80.93 & 86.07 & 100 \\
\hline LSD & 0.05. & & & 10.20 \\
At & 0.01 & & & 14.51 & & \\
\hline & $\mathrm{R} 1$ & 60.22 & 79.58 & 77.27 & 78.40 & 100 \\
F. & $\mathrm{R} 2$ & 61.36 & 70.78 & 76.40 & 89.88 & 100 \\
oxysporium & $\mathrm{R} 3$ & 62.80 & 73.03 & 77.52 & 89.83 & 100 \\
& Mean & 61.46 & 74.46 & 77.06 & 86.03 & 100 \\
\hline LSD & 0.05 & \multicolumn{5}{c}{6.64} \\
At & 0.01 & \multicolumn{5}{c}{9.45} \\
\hline
\end{tabular}

*Values are mean of three replications. Significantly at $\mathbf{P ~} 0.05$ and 0.01 levels.

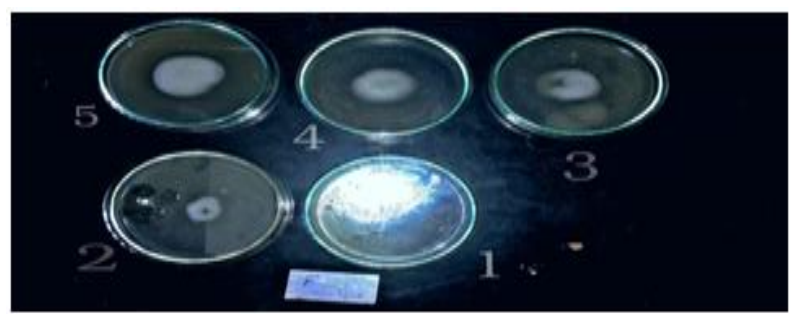

Photo 4. effect of moncut fungicide difrent concentration on $F$. oxysporum on the medium. 


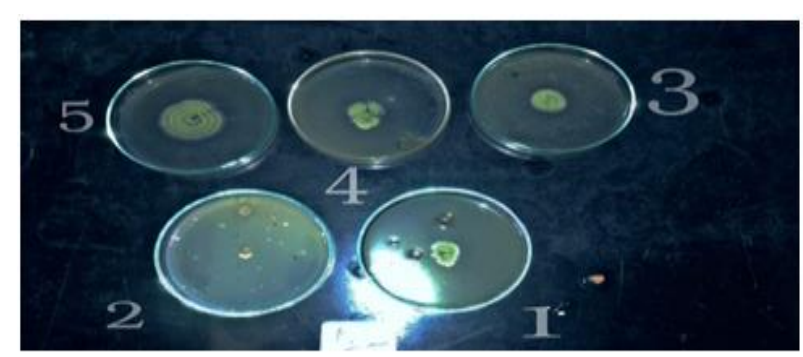

Photo 5. effect of moncut fungicide difrent concentration on $R$. solani on the medium.

Effect of Rhizobium culture filtrate on growth Rhizoctonia solani: Theresults in Table(4) showed that different concentration of rhizobium culturefiltrate effect on linear growth test fungi. Mean linear growth by $(\mathrm{cm})$ was $3.23,1.60$ and0.86 (cm) at 25,50 up to $100 \%$ concentration, from results obviously decreasing in expanded of Rhizoctonia solani mycelium. The results were confirmed that by increasing in efficacy percent which were; $67.92,81.78$ and 90.29 at 25,50 up to $100 \%$ concentration. Also $\mathrm{P}$ at 0.05 was 0.43 and 3.47 , but $\mathrm{P}$ at 0.01 was 0.60 and 4.82 of linear growth $(\mathrm{cm})$ and efficacy $\%$ respectively. These results confirmed by Mazen et al, 2008 and El-Batanony et al. 2007 studied that the inhibitory effect of cultural filtrate of some wild rhizobial isolates against some fungi causing root rot disease of faba ( $R$. solani, Fusarium spp. and F. solani) in vitro and their antimicrobial synergetic effect when combined with Arbuscular mycorrhiza (AM) fungi, also evaluate the bioactivity of Rhizobium spp.isolates and strain to determine the probable mechanisms of the bio-protection.

Table 4. Effect of Rhizobium leguminsarum bv. Phaesoli culture filtrate concentrations on the growth of Rhizoctonia solani.

\begin{tabular}{|c|c|c|c|c|c|c|c|c|}
\hline \multirow{2}{*}{$\begin{array}{l}\text { Rhizobium culture filtrate } \\
\text { conc. }(\%)\end{array}$} & \multicolumn{3}{|c|}{ liner growth $(\mathrm{cm})$} & \multirow{2}{*}{ Mean } & \multicolumn{3}{|c|}{ Efficacy $(\%)$} & \multirow{2}{*}{ Mean } \\
\hline & R1 & $\mathbf{R 2}$ & R3 & & R1 & $\mathbf{R 2}$ & $\mathbf{R 3}$ & \\
\hline $25 \%$ & 2.50 & 3.70 & 3.50 & 3.23 & 70.78 & 62.22 & 70.78 & 67.92 \\
\hline $50 \%$ & 1.50 & 1.60 & 1.70 & 1.60 & 83.14 & 82.22 & 80.00 & 81.78 \\
\hline $100 \%$ & 0.90 & 0.80 & 0.90 & 0.86 & 89.88 & 91.11 & 89.88 & 90.29 \\
\hline $150 \%$ & 0.00 & 0.00 & 0.00 & 0.00 & 100 & 100 & 100 & 100 \\
\hline $200 \%$ & 0.00 & 0.00 & 0.00 & 0.00 & 100 & 100 & 100 & 100 \\
\hline $250 \%$ & 0.00 & 0.00 & 0.00 & 0.00 & 100 & 100 & 100 & 100 \\
\hline Control & 8.90 & 9.00 & 8.90 & 8.93 & 0.00 & 0.00 & 0.00 & 0.00 \\
\hline L.S.D & \multicolumn{4}{|c|}{0.43} & \multicolumn{4}{|c|}{3.47} \\
\hline 0.01 & \multicolumn{4}{|c|}{0.60} & \multicolumn{4}{|c|}{4.82} \\
\hline
\end{tabular}

*Values are mean of three replications.Significantly atP 0.05 and 0.01

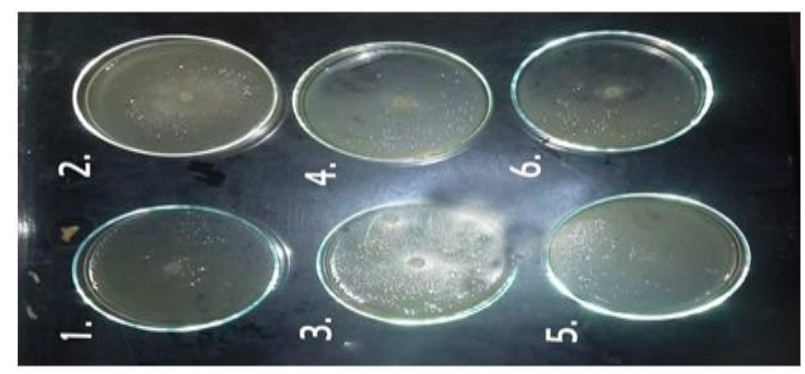

Photo 6. Effect of rhizobium culture filtrate difrent concentration on the growth of $R$. solani on the medium.
Effect of Rhizobium culture filtrate on growth Fusarium oxysporum: Data in Table(5) reviled that effect of culture filtrate of growth Rhizobium liguminsarum $b v$. Phaseioli cells on the linear growth of test fungi of Fusarium oxysporium . The mean results of different concentrations ; 25, 50 and $100 \%$ was; $1.46,1.00$ and 0.93 . Also results was confirmed with efficacy percent which was;87.70,88.71 up to reached91.04 of concentrations 25 , 50 up to $250 \%$ respectively. The results were confirmed by calculate $\mathrm{P}$ at 0.05 was; 0.27 and 1.19 , but $\mathrm{P}$ at 0.01 was; 0.38 and 1.65 of linear growth and efficacy percent respectively. These results was agreement by Mazen et al, 2008 and El-Batanony et al. 2007 .

Table 5. Effect of Rhizobium leguminsarum bv. Phaesoli culture filtrate on growth of Fusarium oxysporium on medium.

\begin{tabular}{|c|c|c|c|c|c|c|c|c|}
\hline \multirow{2}{*}{$\begin{array}{l}\text { Rhizobium-filtrate conc. } \\
(\%)\end{array}$} & \multicolumn{3}{|c|}{ liner growth $(\mathrm{cm})$} & \multirow{2}{*}{ Mean } & \multicolumn{3}{|c|}{ Efficacy (\%) } & \multirow{2}{*}{ Mean } \\
\hline & R1 & $\mathbf{R 2}$ & R3 & & R1 & $\mathbf{R 2}$ & $\mathbf{R 3}$ & \\
\hline $25 \%$ & 1.90 & 1.30 & 1.20 & 1.46 & 88.22 & 88.39 & 86.51 & 87.70 \\
\hline $50 \%$ & 1.00 & 1.00 & 1.00 & 1.00 & 88.63 & 88.76 & 88.76 & 88.71 \\
\hline $100 \%$ & 1.00 & 0.90 & 0.90 & 0.93 & 88.76 & 89.88 & 89.88 & 89.50 \\
\hline $150 \%$ & 0.90 & 1.00 & 0.90 & 0.93 & 89.77 & 88.76 & 91.01 & 89.84 \\
\hline $200 \%$ & 0.90 & 0.80 & 0.80 & 0.83 & 88.76 & 89.88 & 89.88 & 89.50 \\
\hline $250 \%$ & 0.80 & 0.80 & 0.80 & 0.80 & 90.90 & 91.12 & 91.12 & 91.04 \\
\hline Control & 8.70 & 8.90 & 8.90 & 8.83 & 00.00 & 00.00 & 00.00 & 00.00 \\
\hline L.S.D & \multicolumn{4}{|c|}{0.27} & \multicolumn{4}{|c|}{1.19} \\
\hline 0.01 & \multicolumn{4}{|c|}{0.38} & \multicolumn{4}{|c|}{1.65} \\
\hline
\end{tabular}

*Values are mean of three replications. Significantly at p 0.05 and 0.01 levels. 


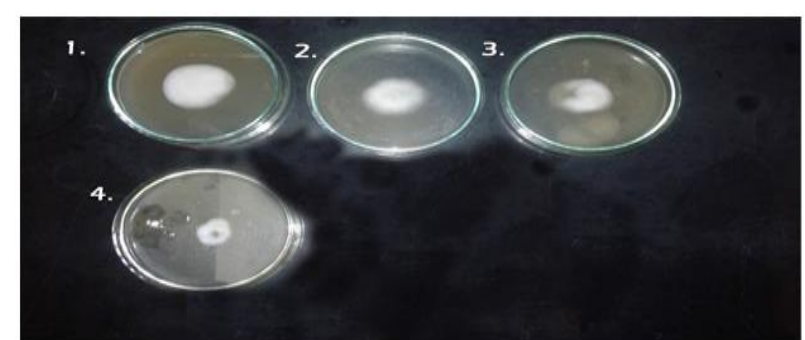

Photo 6. Effect of rhizobium culture filtrate difrent concentration on the growth of $F$. oxysporum on the medium.

\section{CONCLUSION}

This research was conducted to investigation the effect of antagonistic some microorganisms are; Rhizobium leguminsarum biov. Phaseioli as organism oppsite organism or culture filtrate different concentrations, Bacillus subtilus, Pseudomonas fluoresense, Trichoderma album and T. hamatum. On the test organism Fusarium oxysporum and Rhizoctonia solani on the medium all antagonistic organisms gave dcreasing in growth linear and inhibition percent by different degres. But striking Rhizobium theirfore bring organism or culture filtrate treatment which gave efficacy percent reached to $91.04 \%$ on fusarium at $250 \%$ in the effect up to 90.29 with Rhizoctonia solani at $100 \%$ filtrate concentration compared with control and moncut fungicide. These results support application bioagents as biocontrol to environmental integrity, public health and save food production.

\section{REFERENCES}

Abd-Elkhalek, M. S, H., H. Elsebaay and M. A. Sohsah (2018) Actinomycetes bioactive compounds isolated from compost. Egypt. J. Microbiol. Vol. 50, May, 158-169.

Ahmed, M. F. A.(2017) Effect of Biological Control of Root Rot Diseases of Strawberry Using Trichoderma spp. Middle East J. of Appl. Sciences .Vol. 07 Issue :03 P. 482 - 492.

Amany H., A. Mohamed , A. Derbalah (2016) Unconventional alternatives for control of tomato root rot caused by Rhizoctonia solani under greenhouse conditions. J. OF PLANT PROT. RES. 9: 298-306.

Chao WL.(2002). Antagonistic activity of Rhizobium spp. against beneficial and plant pathogenic fungi, Letters in Applied Microbiology; 10: 213-215.

Defago G, CH. Berling, U. Burger, D. Haas, G. Kahr, C. Keel, C. Voisard, P. Wirthner, B.Wurthrich (1990). Suppression of black root rot of tobacco and other root diseases by strains of Pseudomonas fluorescens: Potential applications and mechanisms. In: Horny, D (Eds.), Biological control of soil borne pathogens 1990; pp: 93-108.

Deshwal, K., R. Dubey and D. Maheshwari, (2003). Isolation of plant growth-promoting strains of Bradyrhizobium (Arachis) sp. with biocontrol potential against Macrophomina phaseolina causing charcoal rot of peanut. Current Sci., 84 (3): 443-448.
Driks, A. (2004). The Bacillus spore coat.Phytopathology 94: 1248-1251.

Ehteshamul-Haque, S. and A.Ghaffar. (1993). Use of Rhiozobia in the control of root rot diseases of sunflower, okra, soy bean and mung bean. J. Phytopathology, 138: 157-163.

El-Batanony, N.H., O.N. Massoud, M.M. Mazen and M.M. Abd El-Monium (2008). The Inhibitory effects of cultural filtrates of Some Wild Rhizobium spp. Global Journal of Biotechnology \& Biochemistry 3 (1): 32-41.

El-Mehalawy, A.A., (2004). The Rhizosphere yeast fungi as biocontrol agents for wilt disease of kidney bean caused by Fusarium oxysporum. Intl. J. Agric.Biol., 6 (2): 310-316.

EL-Sebaay, H. H. ; Amal, E. A. EL-Shehawy; and A. A. A. Mohamed (2016) .The antagonistic effect of some soil microorganisms on Rhizoctonia solani causing damping-off in soybean. Al-Azhar. J.Agric.Res., (June)Vol.27, pp 353-367.

Elsebaay, H. H.(1995). Microbiological studies on rhizosphere of some plants resistant and susceptible by wilt. Thesis of M.sc. Fac.of Agric.Al-Azhar, Univ. Cairo.

Essalmani H,and H. Lahlou (2002). In vitro antagonistic activity of some microorganisms toward Fusarium oxysporum f.sp. lentis. crypto-mycol. 23:221-234.

Estevez de Jensen C., J.A. Percich and P.H. Graham (2002). The effect of Bacillus subtilis and Rhizobium inoculation of dry bean seed on root rot severity and yield in Minnesota. Annu Rep Bean Improv Coop, 45: 98-99.

Ghada A. A. El-Kolaly and M. A. Abdel-Sattar(2013) Biological and Chemical Control of the Sudden Wilt Disease of Cantaloupe in Egypt. Journal of American Science ;9(11) 100-108.

Gomez KA and AA Gomez (1984). Statistical procedures for agricultural research $(2 \mathrm{Ed})$. John Wiley and Sons, New York, pp. 680.

Hamdia Z. A, A. Abdul Qader, A. A. Abdullah, H. M. Saood, A. S. Mohammed and S. D. Salman(2017).Antagonistic activity between Bacillus subtilis, Pseudomonas sp. rc, Azospirillum brasilense, Rhizobium meliloti and certain fungal pathogens under laboratory conditions.Asian J. of Sc. and Tech.Vol. 08, Issue, 05, pp.4718-4728.

Ibrahim E. E., K. Haggagb, and H. Abd-El-Khair(2016) Compatibility of Trichoderma spp. with Seven Chemical Fungicides Used in the Control of Soil Borne Plant Pathogens. Res. J. of Pha., Bio. and Chem. Sci. 7(1) P. 1774-1799.

Jacobsen, B.J., Zidack, N.K. and Larson, B.J. (2004).The role of Bacillus-based biological control agents in integrated pest management systems: Plant Diseases. Phytopathology 94:1272-1275.

Karima H.E. Haggag and N. El-Gamal ( 2012) In vitro Study on Fusarium solani and Rhizoctonia solani Isolates Causing the Damping Off and Root Rot Diseases in Tomatoes. Nature and Science 10(11):1-10. 


\section{El-Sebaay, H. H. and A. B. El-Sayed}

Kishore G, Pande S, Podile A. (2005). Biological control of collar rot disease with broadspectrum antifungal bacteria associated with groundnut. Candian J. Microbiol; 51:123-132.

Kloepper, J.W., Rodr'ýguez-K'abana, R.,Zehnder, G.W., Murphy, J.F., Sikora, E. and Fern'andez, C. (1999). Plant root-bacterial interactions in biological control of soil-borne diseases and potential extension to systemic and foliar diseases. Australian Plant Pathology 28: 21-26.

Mazen M., N. El-Batanony, M. Abd El-Monium and O. .Massoud(2008). Cultural filtrate of Rhizobium spp. and Arbuscular Mycorrhiza are potential biological control agents against root rot fungal diseases of faba bean.Global J. of Biot. \& Bioch. 3 (1): 32-41.

Shanker K. P. and S. R. Chandel(2014). Efficacy of Pseudomonas as biocontrol agent against plant pathogenic fungi.Int.J.Cur.Microbiol.App.Sci. 3(11) 493-500.
Shoukry A. A., H. H. El-Sebaay and A. E. El-Ghomary (2018). Asessment of Indole Acetic Acid Production from Rhizobium leguminosarum Strains. Cur. Sci. Int. Vol.: 07 Issue: 01 Jan.- Mar. P.: 60-69.

Steel R.G, H Torrie and DA Dickey (1997). Principles and procedures of statistics. McGraw Hill Book Co. Inc., New York.

Titiya, C.H., B.Eakaphun, W. Nisa, and S.Tipaporn, (2007).Screening of Bacillus spp. Suppressing The Infection of Trichoderma sp.In Mushroom Cultivation. KMITL J. of Sci. and Tech. 7:19-27.

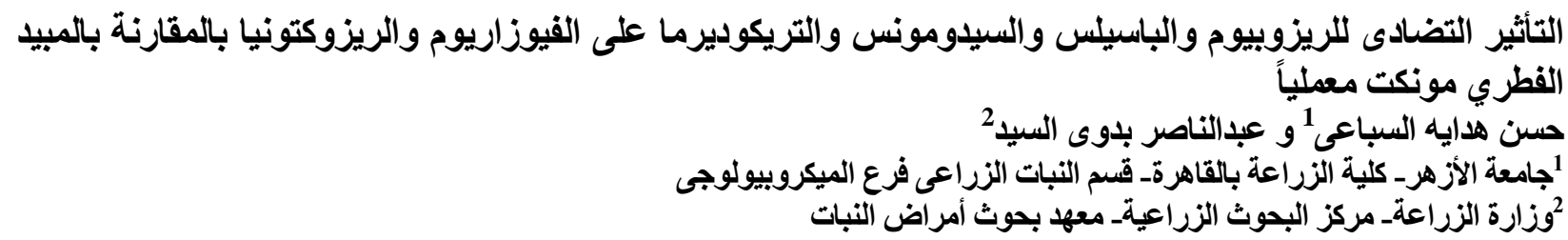

اجريت اختبارات هذا البحث فى عام 2018م لدراسة التأثير التضادى ببكتيريا ريزوبيوم فاصو لايى وباسيلس ستيلس وسيدوموناس فلوريسنس وفطرتريكوديرما ألبم و تريكوديرما هماتم على فطرى فيوز اريوم أوكسيسبوريوم وريزوكتونيا سولانى باتئي بالمقارنة بالمعاملة بالمبيد

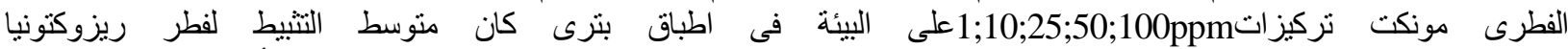

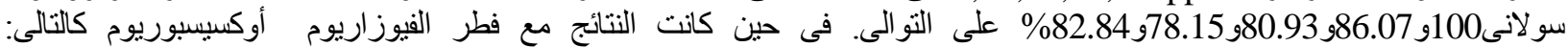

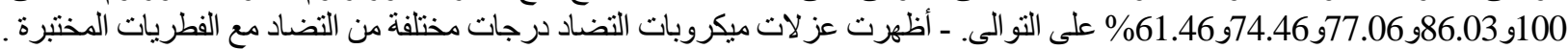
ـ كان أعلى متوسط درجات تضاد بين فطر ريزوكتونيا سو لانى و

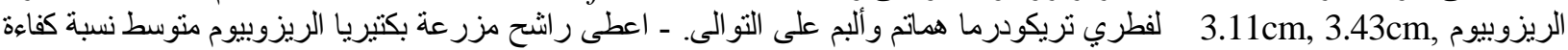

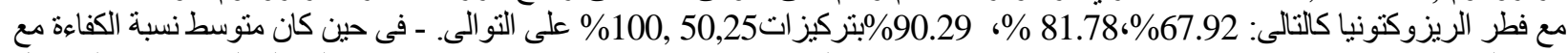

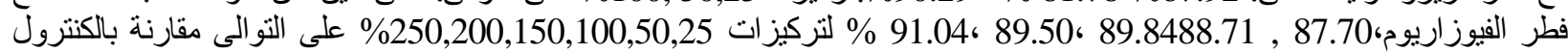
و المعاملة بالمبيد الفطرى مونكت بتركيزات مختلفة، اضاقة لتثبيت نتروجين الهو اء الجوى وانتاج منظمات نمو النبات وزيادة خصوبة التربة. 